\title{
Teachers and Polish children: capturing changes in the linguistic field
}

Article

Accepted Version

Flynn, N. (2019) Teachers and Polish children: capturing changes in the linguistic field. British Journal of Sociology of Education, 40 (1). pp. 65-82. ISSN 0142-5692 doi: https://doi.org/10.1080/01425692.2018.1481366 Available at https://centaur.reading.ac.uk/77405/

It is advisable to refer to the publisher's version if you intend to cite from the work. See Guidance on citing.

To link to this article DOI: http://dx.doi.org/10.1080/01425692.2018.1481366

Publisher: Taylor \& Francis

All outputs in CentAUR are protected by Intellectual Property Rights law, including copyright law. Copyright and IPR is retained by the creators or other copyright holders. Terms and conditions for use of this material are defined in the End User Agreement.

\section{www.reading.ac.uk/centaur}

\section{CentAUR}

Central Archive at the University of Reading

Reading's research outputs online 


\title{
Teachers and Polish children: capturing changes in the linguistic field
}

\begin{abstract}
This article presents original insights into the English learning experiences of Polish children, and contributes a longitudinal perspective on teachers' relationships with them. Data from interviews conducted in 2016 with primary school teachers, Polish children and their parents are compared with outcomes from an earlier study ending in 2009, in order to examine whether teachers' practice for their Polish children has persisted or changed. Previously, findings suggested that teachers in England are constrained by a monolinguallyoriented curriculum and that they identify Polish children as a 'model minority'. In the current study, interviews with teachers, parents, and children were used to develop and question these findings. Using Bourdieuian notions of linguistic field, habitus and capital, data analysis illuminates: the changing responses of teachers to migration; the ways in which teachers' pedagogy has adapted for children who have English as an additional language; and the fluid nature of children's linguistic identities.
\end{abstract}

Keywords: English as an additional language (EAL), Bourdieu, teachers' pedagogy, Polish children, migration

\section{INTRODUCTION}

Following Poland's accession to the EU in 2004 Polish citizens rapidly became the largest migrant group living in England (ONS, 2011) and, by 2011, Polish had become the language spoken by the largest number of people after English. This shift from most migrant families in England having home languages such as Urdu, Punjabi, and Bengali, to Polish, in the 
space of just a few years, is worthy of study not least because it has impacted not only on schools serving diverse communities but also on schools unaccustomed to ethnic or linguistic differences (Author, 2013a).

A comparative study reflecting on Polish children's English language learning experiences, and that of their teachers, is timely. Firstly, findings relevant to research carried out when migration is new need to be revisited once the 'newness' has subsided because migrants negotiate their environments differently over time (Ryan, Lopez Rodriguez, \& Trevena, 2016). Moreover, very few studies designed when Poles first arrived after 2004 were longitudinal because it was unclear how this migration would play out over time (ibid).

Secondly, the educational context in which Polish pupils and their teachers were studied when the children were newly arrived has changed significantly. Since then the numbers of children with English as an additional language (EAL) in schools in England has risen to almost twenty percent of the primary school population (DfE, 2017). Furthermore, the National Curriculum for English - the mandatory language and literacy policy that teachers in England must use to both teach and assess pupils - has become more monolingually-oriented since 2014 (Leung, 2016). Concurrently, resourcing of support for learners with EAL has dropped since 2010 when a change of government in the UK led to reductions in funding to support English language learners (Strand, Malmberg, \& Hall, 2015). Thus teachers operate in a linguistic field of dwindling guidance and resources despite a need to teach a growing population of English language learners. 
With the express intention of observing persistence and change over time, this article employs Bourdieuian field theory (Grenfell \& James, 2004) to map where variations in both the curriculum for English and the pupil demographic have impacted on and are reflected in the classroom experiences of Polish children and their teachers. As such it offers an internationally pertinent contribution to research at a time when the impact of migration is being felt in schools globally.

\section{Linguistic field, linguistic capital, and linguistic habitus}

Bourdieu's methodologically conjoined notions of field, capital and habitus present the researcher with ways of seeing that are well-adapted to studies of language and literacy teaching (Author, 2015a; Grenfell, 2012b); particularly when drawing on his work which forensically examines the relationship between language and power (Bourdieu, 1991). His concepts are particularly valuable for a study of migrant children's developing use of English because Bourdieu recognises schools as sites (fields) which reproduce social and cultural inequalities (Bourdieu \& Passeron, 1990; Harker, 1984). Use of Bourdieu's tools of practical logic throws light on how education (the field) structures teachers' practice and dispositions (habitus) towards their pupils, and on how this habitus determines what teachers value in the classroom (capital).

In the case of the teaching of English in England, the educational field in which teachers operate is mapped out by a National Curriculum for English (DfE, 2013) which is mandated in most state-run schools. There has been a nationally imposed curriculum since 1989 which has gone through successive iterations; the most recent being National Curriculum 2000 (DfES/QCA, 1999) and National Curriculum 2014 (DfE, 2013).The scale and reach of this 
documentation means that the National Curriculum for English is an expression of the rules of the linguistic field because its wording represents the intentions of policy-makers (May, 2012). Of relevance in this study is that the two versions of the National Curriculum referred to above were designed by governments of very different political persuasion: pre-2010 education ministers were of a Labour (left-leaning) government whilst since 2010 education ministers have been of a centre or 'right-wing' orientation.

Symbolic of this difference in mind-set is one particular change between the most recent National Curriculum for English and its predecessor. This is the implementation of demanding tests for 7 and 11 year olds which examine explicit knowledge of spelling, punctuation, vocabulary and grammar (referred to by the acronym $\mathrm{SPaG}$ ) in ways that challenge even native-speaking English children. This might be interpreted as indicative of policymakers' determination to create an essentially monolingual curriculum and assessment structure (Safford and Drury, 2013; Leung, 2016). Implying that teachers in England will feel a sense of either constraint or agency in delivering its very particular expectations depending on their own subject knowledge (Author, 2013b; Hardy, 2012).

Furthermore, while policy-related guidance in the years before 2010 included a number of publications for the teaching of children with EAL (DfES, 2006 inter alia), advice for teachers with pupils with EAL published since 2010 is very limited. There is a school of thought that the National Curriculum has always been shaped for monolingual learners and that a lack of 'subject status' for EAL renders it largely invisible as a curriculum concern and therefore absent from the thinking of policy makers (Leung, 2001). This also means that the teaching of children with EAL is not seen as a necessary strand of professional subject 
knowledge for pre-service or in-service teachers (Leung, 2016) nor is it prioritised by schools as an institutional development need (Anderson, Foley, Sangster, Edwards, \& Rassool, 2016)

In the absence of guidance for teachers of EAL learners in the National Curriculum, research identifies effective pedagogy for new language learners as: talk-based and involving social interaction; drawing on children's first language where possible; allowing time for explicit introduction of the form and function of the new language; and knowledge of children's proficiency in their home languages (Lucas, Villegas, \& Freedson-Gonzalez, 2008). However, an understanding of appropriate pedagogy for EAL as part of teachers' 'professional capital' will manifest itself in different ways according to teachers' experiences and dispositions (habitus) (Author, 2013b). Moreover it is recognised that in general teachers feel under-prepared for the teaching of multilingual children. (Anderson et al, 2016; Murphy \& Unthia, 2015).

The twin developments of a grammar-oriented curriculum and a lack of policy for the teaching of EAL mean that, in Bourdieuian terms, schools and classrooms currently play very significant roles as structures within the linguistic field that can support or inhibit the learning of English for non-native speakers. Bourdieu identifies language as a special kind of field that transcends all others in that it is the medium for communication (Bourdieu, 1977; Grenfell, 2012a) and he classifies the capital related to this field as linguistic capital (Bourdieu, 1991). Teachers may either celebrate or supress languages other than English and this positions the classroom as a linguistic marketplace where proficiency in a dominant, capital-rich language like English gives access to social and cultural capital in the form of friendships and academic success (Luke, 2008). 
Teachers' assumptions and dispositions (habitus) towards their multilingual pupils will dictate whether that relationship is transformative or oppressive (Mills, 2008). There is the potential for negative relationships where teachers of English view the language that their pupils use as lacking in social and cultural capital. Oppression might occur where teachers' responses to children's languages (teachers' linguistic habitus) are reproductive; where they reinforce assumptions about limited potential rather than uncovering true potential (Luke, 2008). Conversely, where teachers consciously adapt their practice for their English language learners, the habitus may have both reproductive and transformative possibilities (Bourdieu \& Wacquant, 1992) in breaking down barriers to achievement for minority groups (Mills, 2008).

\section{Polish children and their teachers in the linguistic field}

Research has tracked a broadly positive response to what has been coined a 'new migration' of Poles (Favell, 2008); not least because Polish workers are perceived as 'hard-working' and so are their children. Polish children have been constructed by their teachers as a 'model minority' (Author, 2013a) and this feeds 'elective affinities' (Author, 2013b; Grenfell \& James, 1998); mutually-binding positive relationships between teacher and pupil. This affinity is strengthened by Polish parents' aspiration for their children to do well in school (Tkacz \& McGhee, 2016). However, taking into account the discussion above, Polish children, as EAL learners, must still negotiate their school status in a linguistic field that is designed for monolingual English speakers (Author, 2013b; Leung, 2016).

Common to all of the studies reporting the Polish migration experience is the role of language; specifically the association of learning English with earning cultural and social 
capital in the shape of better academic outcomes and work-related opportunities (Tkacz \& McGhee, 2016). For Polish children, research identifies that learning English is central to their sense of enjoyment and integration (Moskal, 2016). However, acquiring English is also related to both 'anxiety and resistance' as pupils report that learning their new language is very difficult (p. 147).

Outside mainstream schooling there has been a growth in complementary Polish Saturday schools which children attend to maintain their home language, and Polish parents regard this as important in terms of maintaining a Polish identity (White, 2016). Thus Polish children are under pressure from parents to maintain proficient Polish and under pressure from school to become proficient in English. Additionally, migrant children are likely to act as 'language brokers' for parents with poorer English and are therefore conduits for their parents' access to cultural and social capital (Cline, Crafter, O’Dell \& de Abreu, 2011; Devine, 2009). In essence it appears that children with EAL are required to develop a fluid linguistic identity that can facilitate their own capital ownership, and that of their families, as they negotiate the linguistic fields of home and school (p.10).

In an educational field where mention of the needs of EAL pupils is vague, this article contributes valuable insights into the current state of teachers' professional understanding of EAL pedagogy in the face of curriculum and demographic change, and into how this plays out for one specific group of children. In doing so it lays bare the linguistic field of the classroom and responds to research that calls for the disambiguation of policy from practice for EAL (Author, 2015a; Gerrard \& Farrell, 2013; Safford and Drury, 2013). 
In order that the analysis might uncover changes, rather than reproduce earlier interpretations, research questions were designed not only to allow for comparison with earlier findings but also to reveal differences.

Research questions were:

1) How has primary school English teaching for EAL learners changed in response to demographic and curriculum changes between 2009 and $2016 ?$

2) What are Polish children's experiences of English language and literacy development in primary school?

\section{METHODOLOGY}

Methodologically the research for this article drew on and contributes to consideration of Bourdieuian field theory. This theory seeks to uncover relationships between agents and their circumstances that might otherwise be hidden; it demands that the researcher thinks relationally in order to understand how particular times and social contexts affect positions taken by individuals (Grenfell \& James, 2004). Bourdieuian field theory also promotes conscious reflection and reflexivity in the researcher in order to situate and historicise the scholar's point of view within the data analysis (Bourdieu, 1990b; Kenway \& McLeod, 2004) and this makes it well-suited to comparison of data sets from different time periods.

Bourdieuian analysis is not unproblematic; indeed, many question researchers' application of the habitus (Reay, 2004). However, joining Bourdieuian ways of thinking to constructivist grounded theory (Charmaz, 2006) for the earlier study afforded a practised rigour with use of Bourdieu's toolkit that supported data analysis in the current study. This methodology is 
explained elsewhere (Author, 2015a, 2015b) and its valuable 'plasticity' is highlighted by Stahl (2016, p. 1096).

\section{Research design}

In the first study (Author, 2013a, 2013b), based on data collected between 2007 and 2009, interviews were undertaken with ten teachers in five schools in one local authority, and with staff from the local authority EAL support team, in a county in England which had experienced a sudden rise in Polish children in its primary schools. Outcomes identified that: the English curriculum structure constrained teachers' agency to provide an adjusted curriculum for their Polish children; and that teachers construct Polish children as a 'model minority'.

In the current study interviews were held in 2016 with teachers, pupils and their parents in four schools in the same Local Authority; Polish children had by then become the largest group of non-native speakers in this region's schools. Potential schools were selected from among those where local authority admissions data showed a high, or a growing, number of Polish children on roll in spring 2016. The four schools chosen were those who indicated their willingness to take part and Head teachers acted as gatekeepers for this. Thus, as with the first study, the participants were an opportunity sample of schools that shared characteristics relating to their pupil demographic.

It was intended that at least one teacher, child, and parent from each school would be interviewed, and two local authority EAL consultants (Table 1). While this was recognisably a small sample, it matched the earlier study in scale. As in the first study, the use of in-depth interviews that is practical with a smaller sample yielded rich, thick data for the fine-grained 
analysis and theoretical contemplation that is appropriate to researching naturalistic settings (Crouch and McKenzie, 2006).

\section{Table I Participants and schools}

Ethical considerations included the need for informed consent and participation in interviews from parents who might not speak or read in English. This was facilitated by an interpreter who: translated the project information and consent letters; supported dialogue in Polish during the interviews; and transcribed post-interview. Ethical approval was given through the (author's institution) ethics committee.

\section{The Coding Process}

Coding in the earlier study reflected Bourdieu's concepts of linguistic field, habitus and capital and included development of a code entitled 'professional capital' which referred to teachers' subject knowledge for teaching children with EAL.

In the current study an elaborative coding approach was employed that drew on the codes from the first study in a 'top down' approach to seeking meaning in the text of the interview transcripts (Auerbach \& Silverstein, 2003). Elaborative coding is used where two or more studies of sufficient similarity are conducted and the researcher uses codes created in one study in order to revisit, question and deepen understanding in a follow-on study (Saldana, 2016). It assumes a reflexive researcher stance, in keeping with Bourdieuian practice, that allows for the generation of new codes and refined theoretical constructs. It also supports insights into the effect of time on the research field (Grenfell \& James, 2004) and was therefore particularly pertinent as the analytical tool for this study. 
Overarching codes from the earlier project were employed and elaborated in analysing the current data set in order to capture the differences of experience participants might have in relation to the same themes (Saldana, 2016). The codes' identities endured from the earlier study through multiple iterations, embracing revised insights which supported a theorised narrative of participants' stories (Auerbach \& Silverstein, 2003). The seam of research related to Polish migration and schooling was included in the analysis, and this provided some external moderation to the subjectivity of a lone researcher.

Following several rounds of elaborative coding and revision, word similarity between the different codes was examined in order to eliminate repetition. For example, a new code 'translanguaging', which had appeared relevant from the literature search, was assimilated into the code 'linguistic capital children' or attributed to a newly emerging code 'language brokering'. 'Linguistic habitus' - a weighty code from the earlier study - became integral to the codes relating to linguistic field, linguistic capital. This conflation, which came in the final iteration of coding (Table II), echoed the relational analysis central to Bourdieuian field theory and demonstrated the value of elaborative coding as an enabling tool for this theory.

Table II: Codes arising from the literature review and interview analysis

\section{FINDINGS}

The findings are discussed in relation to the research questions for the current study and to the outcomes from the earlier study. 


\section{Teachers' pedagogy for teaching English in a changing linguistic field}

The impact of changes to the linguistic field, fostered by changes to the curriculum for English and the pupil demographic, emerged clearly. The sense of constraint teachers spoke of in relation to a monolingually-oriented curriculum persisted from the earlier study, but this was off-set by references to EAL-appropriate pedagogy. Teachers expressed unease at the level of grammar-related knowledge and vocabulary required by their Polish children to match national expectations, but at the same time their observations suggested a more nuanced and informed understanding of the teaching of EAL learners. In this way their linguistic habitus was fractured by some discordance in the linguistic field (Bourdieu \& Wacquant, 1992).

For example Anne, a Year 5 teacher in School A, regretted the way in which the National Curriculum's 'age-related' assessment expectations did not reflect what her Polish children could do. Her comment suggests that the monolingual assessment system fails to take account of Polish children's linguistic strengths (Safford and Drury, 2013), and thus does not value the linguistic capital that multilingualism might generate in the longer term:

...there is just no recognition for the journey that they've made and that's very frustrating because there is just so much that they've done but there is no sense of recording their ability.

Anne was exasperated that her pleasure at her Polish children's progress in language acquisition was undermined when it came to practising the level of English they needed for standardised assessment tasks (SATs):

...that's when it starts unravelling, when you get those SATs papers out and you realise that they haven't quite got that. 
Similarly Deborah, a Year 2 teacher in School D, explained that her Polish children had attained well in the Spelling, Punctuation and Grammar (SPaG) test but that the reading comprehension test had caused them difficulties that were clearly vocabulary-related:

Where they did struggle was on the reading comprehension tests where there was a poem called The Parcel .... They didn't understand what a parcel was because they hadn't had that vocabulary and we couldn't explain to them what it was because it was a test.

Deborah's pedagogical understanding of what was needed (professional capital) reflected research findings that EAL learners' knowledge of vocabulary is key for them in accessing curriculum content (Lucas et al, 2008). However this was in conflict with her knowledge that testing reading rather than spoken language reduces Polish children's opportunities to earn cultural capital (Leung, 2016). She was on the one hand empowered to grant access to linguistic capital because of her professional capital, but on the other hand disempowered by the system for assessment because this aspect of the linguistic field was outside her control.

This is in some contrast to Bourdieuian thinking that a fractured habitus might liberate agents' creativity and innovation (Bourdieu and Wacquant, 1992), and illustrates the considerable power exercised by the policy-driven linguistic field in structuring teachers' linguistic habitus (Grenfell, 2004; May, 2012). Teachers' professional capital did not necessarily free them to take a different course of action with their pupils, rather it reminded them of the limitations of their agency to behave in ways other than those dictated by policy. 
Anne and Deborah's acknowledgment of the oppressive structure of a monolingual curriculum that diminishes Polish children's potential to succeed is a source of concern for the profession, but also a source of celebration. Their discourse reflected a more sophisticated articulation of how the English assessment system is 'unfair' when compared with the earlier study; when teachers had expressed a generalised sense of despair at the children being unprepared for national testing at 7 or 11 (Author, 2013b).

These teachers were not willing partners in restricting Polish children's access to linguistic capital (Bourdieu, 1991; Luke, 2008). When removed from consideration of the curriculum's testing requirements, it was clear that practitioners' linguistic habitus was defined by a wish to support their Polish learners rather than to reproduce inequalities (Harker, 1984). In this respect there was evidence that teachers' relationships with pupils were more likely to be transformative than oppressive (Mills, 2008), despite the demands of the curriculum on them.

Deirdra, a learning support assistant in school D, described the ways in which she worked with teachers across her school to target children's language development needs.

....the kind of support that we have identified that the children need is either preteaching vocabulary for topics that we're about to cover or to pre-teach some grammar structure for a piece of writing or a type of writing that we are hoping to achieve within the next week or so.

This was evidence of the ways in which schools' own structures for teaching support had evolved positively in terms of what was happening to support EAL learners. While the curriculum had become more associated with a monolingual habitus than its predecessor, this 
was being subverted by schools' growing knowledge base of how to plan for multilingual children. Current research paints a negative picture of how schools are managing support for EAL learners (Anderson et al 2016; Moskal, 2016), so this observation of growth in expertise was unexpected.

Further evidence of an enriched linguistic field was apparent in conversations with the Local Authority team; all four schools drew on the services of these EAL consultants. Since the first study, this service had evolved several different ways of coping with the rising numbers of Polish learners in its schools: installation of a dedicated phone line for Polish parents; a growth in schools using a scheme which fostered children as peer-interpreters for new arrivals; and employment of four Polish bilingual assistants. Catherine, an EAL consultant in place since the earlier study, commented on the ways in which responses to Polish migration had become more of a 'norm':

So because they (the schools) are familiar with it, they're more relaxed about it... and they've built up banks of resources and we have also bought ... dual language stories in Polish, that kind of thing. So we're more okay with those families and those children. Us as a team, I mean, as well as our schools.

Thus the sense of crisis and panic noted by the LA EAL lead in the earlier study (Author, 2013b) had not persisted in relation to Polish children in school; their presence had become part of schools' everyday identities. In this respect, teachers' agency to accommodate linguistic difference had improved over time. 
The contradictory picture of a discordant yet enhanced linguistic field was apparent in the differences between teachers' reflections on what they are asked to do by policymakers versus their descriptions of what they were actually doing. Conversations with both the teachers and the Local Authority indicated that they were actively supporting Polish children's education despite the changed shape of the curriculum. From this we might assume that teachers' professional capital is so much a part of their unconscious habitus that they do not recognise their own improved capacity to respond appropriately to linguistic differences. Perhaps differing values are attributed to different types of professional capital in the linguistic field.

\section{Demographic changes in the linguistic field: Polish children as a 'model minority'}

The linguistic field, in terms of the pupil demographic, had changed in comparison to the first study in that the numbers of Polish children entering school at 5 years old (Reception year) were rising rapidly and these children tended to have been born in the UK. This shift featured clearly in all four schools and is captured here by Bridie from school B:

In our current Year 6 class, 1 of 34 speaks Polish at home, but in our current Reception class.... well over half of them speak Polish. So it's increased year on year, until we're in a position where suddenly an awful lot of Polish families are coming in and .... we're oversubscribed.

This increase in Polish pupil numbers meant that there was the potential for variances in teachers' responses to their children; because with volume comes diversity and a greater likelihood of social differences (White, 2016:17). 
In the earlier study teachers' responses to their Polish children were largely very positive and appeared to reflect what other research had defined as a 'model minority myth'; that Polish children were eager to learn and highly motivated (Author, 2013a). This was in conflict with outcomes from more recent research which identified the tensions and stresses for Polish children learning English in school (Moskal, 2016) and was therefore an important finding to revisit.

Among teachers of older children in KS2 the portrait of the model Polish learner largely persisted. Carmella (school C) talked about her Year 6 pupil Karolina thus:

...if you went in and spoke to all the children you probably wouldn't be able to identify which one was Karolina because she doesn't have a Polish accent, she has absolutely no problems with her English whatsoever.

In her teacher's eyes Karolina's reserves of linguistic capital were rich because of both her English proficiency and her English accent; rather than because she was bilingual. This demonstrated that, even though the teachers had stronger reserves of professional capital for EAL teaching, their linguistic habitus was still aligned with a desire for their pupils' superior English proficiency. For Carmella, as a Year 6 teacher whose pupils are subject to national testing of English by which her school is ranked, this will have been a direct shaping by the linguistic field of her linguistic habitus (Grenfell \& James, 2004).

Aside from English proficiency, praise of pupils' aspirations was a part of the model minority construct in the earlier study and this too persisted. Aron and Agnieszka's teacher (school A) defined her pupils as 'average in ability' but saw in them an attitude that, she felt, set them apart: 
They are driven and I've noticed that before with Polish children. That there is a drive there that's really interesting and it's like a tenacity that, I can't quite put my finger on it but they are desperate to be in the top groups.

Bridie (school B) replicated comments from interviews with other practitioners in 2009 when she said:

I find that the children from Polish families... are from families who really value education... you find the children have that same attitude, and they come into school and they want to learn.

Teachers' discourse suggested that, if anything, the notion of the model minority as being one of 'elective affinities' between teacher and pupil (Grenfell and James, 1998) had intensified in the case of Polish children.

However, the teachers of younger children, who were likely to have more Polish children in their classes, did not necessarily share this idealised view. They had plenty of positive comments to make but these were qualified by their experience of more pupils. Angela, a Year 2 teacher from school A, said:

I think because we have so many Polish children in our school now that there isn't a stereotype.....they are as well-behaved or as mischievous as any other child really...

The linguistic field in the classrooms of younger children had changed substantially and some 'normalising' of Polish children had occurred as a result. Indeed, Angela's view echoes the view from the Local Authority that reception of Polish children and their families was something about which schools were more relaxed: what was new had become familiar. 
Nevertheless, even among the teachers of younger children there were comments that suggested maintenance of a very positive relationship between teachers and Polish children. Polish children want to learn English and they want to work hard, and this is representative, in their teachers' minds, of their ownership of cultural capital (Author, 2013b). Arguably this will have supported the growth of transformative rather than oppressive relationships with the children (Mills, 2008) and these relationships will of themselves have generated pupils' linguistic and cultural capital in the linguistic marketplace of the classroom.

\section{Polish children's experiences of learning English: fluid identities and language brokering}

Outcomes from the children's conversations threw open to question their teachers' responses to them as model learners. They also illuminated a mismatch between teachers' focus on the children's successes in English, and the children's own realities in navigating between linguistic fields at home and in school. Coding identified that they had 'fluid identities' and were often in role as 'language brokers' between each other or between parents and their teachers. This sense of moving between different fields of identity and language-use demonstrated that, for Polish children, the learning of languages and literacies can be bound up with conflicting loyalties (Devine, 2009; Moskal, 2016).

Interviews with the children about their English language acquisition and literacy development were sometimes positive but at other times tinged with the anxiety and conflict recognised in Moskal's study (2016). Talking positively about her memories of coming to school as a Polish speaker, Karolina explained: 
At first all I could say was 'Hi' and my friends were asking me 'What's your name?' and I thought 'whatever are you talking about?' So then I got help from the teachers and from my parents ... and now I'm like, 'how on earth did I learn all that?'

Karolina's use of both her languages in school was something she enjoyed because it allowed her to speak 'in secret' to her best friend who was Polish. Conversely, Karolina suggested that sometimes she felt like she 'didn't belong'. She appeared to accept that her bilingualism allowed her access to the linguistic field of the classroom where English ruled, but the following comment demonstrates her ambivalence about this:

In school I am fully English and the moment I step out of the school I switch to Polish.

Karolina's life seemed to demand her stepping in and out of different linguistic fields, but the interviews with her teacher and mother suggested that the adults around her were unaware of this. Karolina's mother commented that starting school had been 'no problem' for her, yet Karolina's comments were heavy with a sense of responsibility to do well both at home and school, and these two environments were not always compatible. For example, Karolina was aware that her attainment in English language and literacy at school were good - she was outperforming many of her monolingual peers - but this was at the expense of her literacy in Polish:

I think I am a lower Polish reader than I am an English reader because I can't get my head around the different letters. There's a $z$ with a dot, $z$ with a little line... Just difficult.

This anxiety about not doing so well as Polish speakers and writers was echoed by the children interviewed at school A. Both Aron and Agnieszka explained that 'Polish is the 
language at home' but each of these children were anxious that their progress in Polish literacy lagged behind their English literacy. They attended Polish Saturday school but acknowledged that this did not really give them adequate support in developing reading and writing in Polish in the ways that their parents would like. Thus they were privy to assumptions about the relative values of the two languages they used (Bourdieu, 1991) and this was uncomfortable for them.

Conversations with Aron, Agnieszka and Karolina also threw up multiple examples of ways in which the children's fluid linguistic identities meant that they served as language brokers (Cline et al, 2011). In some cases this was positive. For example Agnieszka explained that she and Aron were both 'Young Interpreters' - a scheme pioneered by the local authority to support newly-arrived migrant children - and this was a source of pride for her. In other cases such skilled bilingualism was just a necessary part of everyday living. Karolina's mother noted that her daughter is 'my teacher' when it came to learning English, with no references to the role-reversal inherent in this. Aron explained his home situation:

We need to speak Polish at home because my dad goes to English school right now and my mum is going to start it next year, so they don't really know good English so I need to speak Polish.

Interestingly Aron also had a clear memory of starting nursery with no spoken English and of the help he got from a Polish peer:

Well, before I went to Nursery, I didn't speak English at all, I only spoke Polish. I settled in on the first day, because I had another Polish friend there, he kind of taught me a bit of English as well. 
Thus Aron understood how his social capital - being able to converse in Polish with another Polish speaker - afforded him cultural and linguistic capital in the form of learning to speak English, even at the age of three. Conversely Aron also understood that he needed to maintain his Polish at home because neither of his parents spoke English, and because his summers were spent in Poland with extended family. His dual identity might have meant that he felt that he both belonged and yet did not belong (Anderson et al, 2016), as articulated so clearly by Karolina.

The interviews with the children demonstrated how they needed to negotiate their positions at home and at school in ways that sometimes separated and sometimes combined different linguistic fields. In each field they had differing levels of linguistic capital depending on the view of the adults with whom they were interacting. These observations build on the advice from Anderson et al (2016) that schools should not assume that EAL pupils' identities are binary. Their navigation of linguistic fields, particularly that of the classroom as a linguistic marketplace, is on a more challenging continuum of identity than their teachers, or their parents might understand.

\section{DISCUSSION and CONCLUDING THOUGHTS}

Where researchers sought to study Polish migration in the years after EU accession, longitudinal studies were not planned because of the then-unforeseen scale of this phenomenon (Ryan, Lopez Rodriguez, \& Trevena, 2016). Furthermore, while many studies have tracked the adult Polish migration experience (White, 2016), research in UK schools following the experiences specific to Polish children and their teachers is very limited. 
This study addressed these gaps by offering a school-based perspective over time: it examined what persisted and what changed in the linguistic field for Polish children and their teachers. In reflecting on past outcomes it has offered new and hitherto unexplored insights into the experiences of both children and teachers. Furthermore it has contributed methodologically to exploring the strength of Bourdieuian field theory when used to uncover the relationship between time and agency in educational research (Grenfell \& James, 2004, p. $510)$.

A relationship between time and agency when comparing the two studies was clearly exemplified by teachers' growth in professional capital for their practice with EAL learners; this despite cuts to funding, and a strengthened monolingual mind-set in the curriculum. Between the two studies the numbers of Polish children, and other children with EAL, had grown in schools in the region, and this had acted as a positive driver for potential transformational relationships between the teachers and their children. Where the early study drew a portrait of constraint for practitioners, and limitations imposed by an unconscious and unquestioning response to policy, findings from this study suggest that teachers' linguistic habitus might be dynamic rather than inflexible (Bourdieu \& Wacquant, 1992). Although the small sample size means that findings are by no means generalisable, this is a potentially positive outcome and a challenge to policymakers' actions; which have diminished the visibility of EAL as a teaching and learning priority in the National Curriculum (Leung, 2016).

Although there was clear evidence that teachers' linguistic habitus remained structured by a monolingual linguistic field when it came to pupil assessment, there were attempts to mitigate 
this through the adoption of EAL-oriented teaching strategies. This suggests that a key change to the linguistic field over time has been the development of a subset of practice that could subvert policy makers' monolingual mind-set. Teachers complained about the constraints of the curriculum but this did not stop them trying to teach in ways that match research into EAL pedagogy (Lucas et al, 2008). Thus the potential for reproduction of educational inequalities (Bourdieu \& Passeron, 1990; Harker, 1984) appeared weakened in a linguistic field that was changed by some discordance between policy and practice.

Arguably the tensions identified in the first study between teachers' linguistic habitus and the linguistic field were if anything felt more explicitly by teachers in the current study because of their enhanced subject knowledge. While Bourdieuian thinking directs us to note differences in the value attributed to languages in a linguistic marketplace (Bourdieu, 1991), this study sheds light on the possibility that a similar power struggle goes on between the pedagogical approaches associated with both language use and language acquisition in the classroom. The linguistic field in the classroom emerged in this study as something of a battle ground where teachers' positive growth in professional knowledge for the teaching of English to non-native speakers generated potentially transformative teacher-pupil relationships (Mills, 2008). However, potential is not the same as agency to resist the monolingual mind-set of the linguistic field, and the conversations moved in and out of aspiration to teach in ways that would support EAL learners, tempered with expressions of constraint (Hardy, 2012).

Constraint and some continuation of a monolingual linguistic habitus among the teachers were still present. While the articulation of their practice was more nuanced and informed, this was moderated by their continuing need to show that children's measureable success 
comes with their use of English (Safford \& Drury, 2013). Additionally, there was some lack of understanding of how much children use Polish at home, and limited insight into children's on-going navigation of different linguistic fields; this underscored the extent to which practitioners are very focussed on attainment in English despite their enhanced professional capital relating to second language acquisition and pedagogy.

The reflexive nature of this study, and the use of elaborative coding, posed challenges for the author as researcher in that it required some questioning of earlier findings; this not least because children and their parents were included within the second project. The notion of the 'model minority', so starkly apparent in the vision of 'elective affinities' in the earlier study, was challenged substantially by the inclusion of the children's voices. Children projected a sense of identity that was much more complex than that of the ideal pupil (Moskal, 2016).

While this did not necessarily negate earlier interpretation, it certainly fostered a reconsideration and reflection that questioned assumptions and deepened understanding of what non-native speaking children's experience of the classroom is like. It laid bare the extent to which behaving well and working hard (Grenfell \& James, 1998) can hide children's language learning needs in ways that were hinted at in the earlier research, but which were brought more sharply into focus in the current project. The image of the model minority reflected in teachers' responses was questioned, and found wanting, when reexamined in relation to the children's stories. There is very little research into the feelings of groups of learners identified as model minorities where the learners' voices are heard. This study indicates just how much there is still to understand about their experiences. 
The inclusion of children's perspectives did not only challenge earlier findings, it allowed for the emergence of new findings. The ways in which the children were exposed to 'challenges of identity' that neither their parents nor their English peers had to experience (Devine, 2009) afforded them dual narratives of Polishness and Englishness that need further exploration. Their experience of learning English in school was in conflict with their experiences of trying to learn Polish for the home, meaning that they are sentenced to continuous navigation of competing linguistic fields.

There was also evidence in the interviews with parents of considerable variation in their English proficiency and, although not reported on in detail in this article, there were suggestions of a relationship between social class, English proficiency, social mobility and social capital that echo those found in other studies (Devine, 2009; Tkacz \& McGhee, 2016). Thus, some children's identities as language brokers for their parents meant that they were mediators of their parents' reserves of social and linguistic capital (Cline et al, 2011), and we might ask ourselves to what extent this position as 'family language guardian' is desirable or appropriate in such young people.

The National Curriculum for English, and its associated assessment expectations, structure a linguistic field which is potentially constraining for teachers and potentially reproductive of inequalities for Polish children. Furthermore, it is not the only linguistic field in which Polish children must operate and thus they must deal, linguistically, with more than their teachers and parents might understand. However, the constraint that the linguistic field might confer on teachers in the studies examined in this article does not necessarily reduce their sense of 
agency to make appropriate pedagogical choices for their English language learners, and this is cause for cautious optimism.

The twin drivers of monolingual expectations and an increasingly linguistically diverse pupil demographic are incompatible, and yet accommodated by practitioners. Future research is needed to examine whether the shifting linguistic field, in terms of pupil demographic and the mandated curriculum for English, has impacted on teachers and their EAL learners in other regions and with other home languages. There is very little research that incorporates the voices of all stakeholders - teachers, children and parents - and this is essential if we are to honestly chronicle the narratives of all agents within linguistic fields at home and at school. Such narratives are essential to an evidence base that can challenge policymakers' monolingual habitus and release teachers to make transformative relationships with their multilingual pupils.

\section{Word count 7833}

\section{REFERENCES}

Anderson, C., Foley, Y., Sangster, P., Edwards, V., \& Rassool, N. (2016). Policy, Pedagogy and Pupil Perceptions: EAL in Scotland and England (T. B. Foundation Ed.). Cambridge: University of Edinburgh and The Bell Foundation.

Auerbach, C., \& Silverstein, L. (2003). Analyzing Your Next Study Using Elaborative Coding: The Promise Keeper Fathers. In C. Auerbach \& L. Silverstein (Eds.), Qualitative Data, (pp. 104 - 124). New York: New York University Press. 
Bourdieu, P. (1977). The Economics of Linguistic Exchanges (R.Nice, trans). Social Science Information, XVI(6): 645 - 668.

Bourdieu, P. (1990a). The Logic of Practice (R. Nice, trans.). Cambridge: Polity Press.

Bourdieu, P. (1990b). The Scholastic Point of View. Cultural Anthropology, 5(4): 380 - 391.

Bourdieu, P. (1991). Language and Symbolic Power (R.Nice, trans.) Cambridge: Polity Press.

Bourdieu, P., \& Passeron, J.-C. (1990). Reproduction in Education, Society and Culture (Second ed.). London: Sage.

Bourdieu, P., \& Wacquant, L. (1992). An Invitation to Reflexive Sociology. Cambridge: Polity Press.

Charmaz, K. (2006). Constructing Grounded Theory: A Practical Guide Through Qualitative Analysis. London: Sage.

Cline,T., Crafter,T., O'Dell, L. \& de Abreu, G. (2011) 'Young people's representations of language brokering', Journal of Multilingual and Multicultural Development, 32 (3), 207-220

Crouch, M. \& McKenzie, H. (2006) 'The logic of small samples in interview-based qualitative research', Social Science Information, 45(4): 483-499.

Devine, D. (2009). Mobilising capitals? Migrant children's negotiation of their everyday lives in school. British Journal of Sociology of Education, 30(5): 521-535.

DfE. (2013). National Curriculum in England: English programmes of study: www.education.gov.uk/nationalcurriculum.

DfE (2017) Schools, pupils and their characteristics, SFR 28/2017. London: Department for Education

DfES. (2006). Excellence and Enjoyment: Learning and Teaching for Bilingual Children in the Primary Years DfES 0013-2006PCK-EN. Nottingham: DfES. 
DfES/QCA. (1999). The National Curriculum Framework for Teaching: Guidance for Primary School Teachers in England and Wales. London: QCA.

Favell, A. (2008). The New Face of East-West Migration in Europe. Journal of Ethnic and Migration Studies, 34 (5): 701-716.

Flynn, N. (2013a) Linguistic capital and the linguistic field for teachers unaccustomed to linguistic difference. British Journal of Sociology of Education, 34(2): 225 - 242

Flynn, N. (2013b) Encountering migration: English primary school teachers' responses to Polish children. Pedagogies: An International Journal, 8(4): 336 - 351.

Gerrard, J., \& Farrell, L. (2013). Peopling curriculum policy production: researching educational governance through institutional ethnography and Bourdieuian field analysis. Journal of Curriculum Policy, 28(1): 1 - 20.

Grenfell, M. (2012a). Bourdieu, Language and Education. In M. Grenfell, D. Bloome, C. Hardy, K. Pahl, J. Rowsell, \& B. Street (Eds.), Language, Ethnography and Education (pp. 50 - 70). London: Routledge.

Grenfell, M. (Ed.) (2012b). Bourdieu, Language and Linguistics. London: Continuum.

Grenfell, M., \& James, D. (2004). Change in the field — changing the field: Bourdieu and the methodological practice of educational research. British Journal of Sociology of Education, 25(4): 507-523.

Grenfell, M., \& James, D. (Eds.). (1998). Bourdieu and Education: Acts of Practical Theory. London: Routledge.

Hardy, C. (2012). Language and Education. In M. Grenfell (Ed.), Bourdieu, Language and Linguistics (pp. 170-193): London: Continuum.

Harker, R. K. (1984). On Reproduction, Habitus and Education. British Journal of Sociology of Education, 5(2): 117-127. 
Kenway, J., \& McLeod, J. (2004). Bourdieu's reflexive sociology and 'spaces of points of view': whose reflexivity, which perspective? British Journal of Sociology of Education, 25(4): 525-544.

Leung, C. (2001). English as an Additional Language: Distinct Language Focus or Diffused Curriculum Concerns? . Language and Education, 15(1): 33 - 55.

Leung, C. (2016). English as an additional language - a genealogy of language-in-education policies and reflections on research trajectories. Language and Education, 30(2): 158174.

Lucas, T., Villegas, A. M., \& Freedson-Gonzalez, M. (2008). Linguistically Responsive Teacher Education:Preparing Classroom Teachers to Teach English Language Learners. Journal of Teacher Education, 59(4): 361-373.

Luke, A. (2008). Pedagogy as Gift. In J. Albright \& A. Luke (Eds.), Pierre Bourdieu and Literacy Education (pp. 68 - 92). London: Routledge.

May, S. (2012). Language Policy. In M. Grenfell (Ed.), Bourdieu, Language and Linguistics (pp. 147 - 169). London: Continuum.

Mills, C. (2008). Reproduction and Transformation of Inequalities in Schooling: The TransformativePotential of the Theoretical Constructs of Bourdieu. British Journal of Sociology of Education, 29(1): 79-89.

Moskal, M. (2016). Language and cultural capital in school experience of Polish children in Scotland. Race Ethnicity and Education, 19(1): 141-160.

Murphy, V., \& Unthia, A. (2015). A systematic review of intervention research examining English language and literacy development in children with English as an Additional Language (EAL). University of Oxford: Oxford

ONS. (2011). Polish People in the UK. Retrieved from London: http://www.statistics.gov.uk/cci/nugget.asp?id=2369 
Reay, D. (2004). 'It's all becoming a habitus': beyond the habitual use of habitus in educational research. British Journal of Sociology of Education, 25(4),431-444.

Ryan, L., Lopez Rodriguez, M., \& Trevena, P. (2016). Opportunities and Challenges of Unplanned Follow-up Interviews: Experiences with Polish Migrants in London. Forum: Qualitative Social Research, 17(2): Art 26.

Safford, K. \& Drury, R. (2013) 'The 'problem' of bilingual children in educational settings: policy and research in England, Language and Education', 27(1), 70-81

Saldana, J. (2016). The Coding Manual for Qualitative Researchers (3rd edition). London: Sage.

Stahl, G. (2016). Doing Bourdieu justice: thinking with and beyond Bourdieu. British Journal of Sociology of Education, 37(7): 1091-1103.

Strand, S., Malmberg, L., \& Hall, J. (2015). English as an Additional Language (EAL) and educational achievement in England: An analysis of the National Pupil Database. Oxford: University of Oxford Department of Education.

Tkacz, D., \& McGhee, D. (2016). Polish Migrant Parents of Secondary School Boys in The United Kingdom. British Journal of Educational Studies, 64(3): 357 - 374.

White, A. (2016). Polish migration to the UK compared with migration elsewhere in Europe: a review of the literature. Social Identities, 22(1): 10 - 25. 
Table I: Participants and schools

\begin{tabular}{|c|c|c|c|c|c|c|c|}
\hline SETTING & $\begin{array}{c}\text { School type and } \\
\text { pupil roll }\end{array}$ & $\begin{array}{l}\text { Numbers of } \\
\text { Polish pupils }\end{array}$ & TEACHERS & CHILDREN & $\begin{array}{l}\text { Children's } \\
\text { place of } \\
\text { birth }\end{array}$ & PARENTS & $\begin{array}{c}\text { PARENTS' } \\
\text { UK } \\
\text { ARRIVAL } \\
\end{array}$ \\
\hline \multirow[t]{2}{*}{ School A } & \multirow[t]{2}{*}{$\begin{array}{c}\text { RC* Primary** } \\
\text { urban (408) }\end{array}$} & \multirow[t]{2}{*}{$\begin{array}{l}59 \text { (mostly in } \\
\text { YR and KS1) }\end{array}$} & \multirow{2}{*}{$\begin{array}{c}\text { Angela, Year } 2^{* * * *} \\
\text { teacher } \\
\text { Anne, Year } 5 \text { teacher }\end{array}$} & $\begin{array}{l}\text { Aron (boy, } 10 \text { years } \\
\text { old) }\end{array}$ & England & & \\
\hline & & & & $\begin{array}{l}\text { Agnieszka (girl, } 9 \\
\text { years old) }\end{array}$ & England & & \\
\hline School B & $\begin{array}{l}\text { RC Primary } \\
\text { urban (226) }\end{array}$ & $\begin{array}{c}34 \text { (mostly in } \\
\text { YR) }\end{array}$ & $\begin{array}{l}\text { Bridie, Year } 5 \text { teacher } \\
\text { and EAL coordinator }\end{array}$ & $\begin{array}{l}\text { Bianka (girl) } \\
\text { Bruno (boy), } \\
5 \text { year old twins }\end{array}$ & England & $\begin{array}{l}\text { Bogna mother, also } \\
\text { Polish bilingual } \\
\text { assistant } \\
\text { Bartosz- father }\end{array}$ & 2004 \\
\hline \multirow[t]{2}{*}{ School C } & \multirow{2}{*}{$\begin{array}{c}\text { RC Primary } \\
\text { coastal town } \\
(188)\end{array}$} & \multirow[t]{2}{*}{11} & \multirow{2}{*}{$\begin{array}{c}\text { Charlotte, Year R } \\
\text { teacher } \\
\text { Carmella, Year } 6 \text { teacher }\end{array}$} & $\begin{array}{l}\text { Karolina (girl, } 10 \\
\text { years old) }\end{array}$ & Poland & \multirow[t]{2}{*}{ Cecylia, mother } & \multirow[t]{2}{*}{2007} \\
\hline & & & & $\begin{array}{l}\text { Irena and } \\
\text { Izabella, } 5 \text { year old } \\
\text { twins girls }\end{array}$ & England & & \\
\hline School D & $\begin{array}{c}\text { RC Primary } \\
\text { coastal town } \\
(112)\end{array}$ & 12 & $\begin{array}{c}\text { Deborah, Year } 2 \text { teacher } \\
\text { and EAL coordinator } \\
\text { Deirdra, EAL learning } \\
\text { support }\end{array}$ & $\begin{array}{l}\text { Damian (boy age } \\
\text { 15) } \\
\text { Daniel (boy age 13) } \\
\text { Danuta (girl age 10) }\end{array}$ & Scotland & $\begin{array}{l}\text { Dorota, mother and } \\
\text { parent governor }\end{array}$ & 1998 \\
\hline
\end{tabular}

${ }^{*}$ Roman Catholic, ** English Primary schools teach children from ages $4-11$ years and are divided into phases called Reception (Year R), Key Stage 1 (KS1) and Key Stage 2 (KS2) ***Year group ages YR (4-5), Yr 2 (6-7), Yr 5 (9-10), Yr 6 (10-11)

\begin{tabular}{|c|c|l|}
\hline Local Authority EAL staff (3) & Local authority type & Role \\
\hline Rachael & \multirow{2}{*}{$\begin{array}{c}\text { County authority } \\
\text { in south of England, 150 languages } \\
\text { Catherine }\end{array}$} & EAL adviser \\
$\begin{array}{c}\text { other than English spoken } \\
\end{array}$ & EAL consultant \\
\hline
\end{tabular}


Table II: Codes arising from the literature review and interview analysis

\begin{tabular}{|l|l|}
\hline Code & Definition \\
\hline Fluid identity (children) & Children's expression of their Englishness and/or Polishness \\
\hline Language brokering & $\begin{array}{l}\text { Children's reference to being supported in understanding or supporting understanding of others in } \\
\text { English }\end{array}$ \\
\hline Linguistic capital (children) & Children's sense of success (cultural capital) in English or Polish \\
\hline Linguistic capital (parents) & Parents' sense of their own and their children's use of both English and Polish \\
\hline Linguistic capital (teachers) & $\begin{array}{l}\text { Teachers' perceptions of and responses to children's and family's use of English or Polish - what they } \\
\text { value. Includes unconscious dispositions ( linguistic habitus) }\end{array}$ \\
\hline Linguistic field & $\begin{array}{l}\text { Ways in which teachers' and children's lives are shaped by curriculum expectations (includes linguistic } \\
\text { habitus); the ways in which migration changes schools' behaviours and expectations of teachers' } \\
\text { pedagogy. }\end{array}$ \\
\hline Model minority & Ways in which teachers construct Polish children as hard-working/ able \\
\hline Professional capital (teachers) & $\begin{array}{l}\text { Ways in which teachers demonstrate their understanding of the teaching and learning needs of EAL } \\
\text { learners; includes linguistic habitus as a guide to pedagogical choices. }\end{array}$ \\
\hline Social capital (parents) & Parents' access to support networks with other Polish families, with the RC church, with English families. \\
\hline
\end{tabular}


